\title{
Transaksi Pihak Berelasi: Kompensasi Manajemen Kunci, Kinerja Akuntansi, dan Multiple Large Shareholders
}

\author{
Gandy Wahyu Maulana Zulma ${ }^{*}$, Fitri Chairunnisa ${ }^{2}$, Azolla Degita Azis ${ }^{3}$ \\ ${ }^{1,2}$ Universitas Jambi \\ ${ }^{3}$ Universitas Ibn Khaldun Bogor \\ *Correspondence email: maulanagandi25@unja.ac.id
}

\begin{abstract}
The aim of this study is to examine whether multiple large shareholders held by the company can affect the relation between accounting performance and executive compensation, using panel data of all publicly company in Indonesia (except financialand mining industries) with the research period 2017-2019. The result shows that the existence of 2nd largest shareholders that owns more than 10\% stocks and also if the board has representation from 2nd largest shareholders in the company, it can reduce the positive effect of accounting performance to executive compensation. This research findings could be as an additional literature in financial accounting and corporate governance area, and also for practitioners in Indonesia that if a firm has good controlling function from multiple large shareholders, it can reduce the opportunistic discretion from executive management if the company has performance evaluation based on earnings.
\end{abstract}

Keywords: multiple large shareholders; accounting performance; compensation

\section{PENDAHULUAN}

Dalam rangka meningkatkan nilai perusahaan jangka panjang, pemegang saham memberikan sejumlah insentif atau kompensasi kepada manajemen kunci, termasuk dewan direksi. Hal ini dikarenakan untuk mendorong manajemen memilih metode akuntansi yang tepat bagi keuangan perusahaan, mengindari adanya biaya keagenan, pelanggaran perjanjian utang, serta tidak berperilaku oportunis (Watts \& Zimmerman, 1978; Fields et al., 2001; Conyon, 2006).

Kinerja perusahaan seringkali dikaitkan dengan insentif kompensasi manajemen. Conyon (2006) mengemukakan bahwa apabila kinerja keuangan perusahaan turun, maka kompensasi direksi juga akan mengalami penurunan, begitu pula sebaliknya. Sehingga, manajemen akan lebih sensitif terhadap kinerja akuntansi (laba) perusahaan karena dapat mempengaruhi besaran kompensasi. Namun demikian, kebijakan mengenai kompensasi yang didapatkan oleh direksi tentunya harus diawasi, agar direksi tidak melakukan penyimpangan seperti melaksanakan diskresi akrual dan pemilihan kebijakan akuntansi tertentu demi meningkatkan insentif kompensasi yang akan diterimanya (Fisher et al., 2005).

Untuk dapat menurunkan oportunistik manajemen dan mencegah adanya keuntungan pribadi yang ditimbulkan dari pengukuran kinerja berdasarkan laba perusahaan, menurut Amdouni dan Boubaker (2015) dapat diminimalisir apabila di suatu perusahaan terdapat dua atau lebih pemegang saham terbesar (multiple large shareholder), karena pemberian besaran insentif kompensasi manajemen akan diawasi oleh pemegang saham terbesar kedua.

Berdasarkan beberapa hasil penelitian terdahulu terkait dengan kinerja perusahaan dan kompensasi manajemen hasilnya masih beragam. Cheng \& Farber
(2008), Banker et al, (1996), Cheng et al. (2015), Chen (2013), Theeravanich (2013), dan Parthasarathy et al. (2006) telah meneliti mengenai kinerja akuntansi dan kompensasi, namun hasilnya masih beragam, ada yang menemukan bahwa tidak ada pengaruh antara kinerja dan kompensasi, namun ada pula yang menemukan pengaruh positif (Theeravanich, 2013). Selain itu, Amdouni dan Boubaker (2015) belum memaparkan lebih jelas mengenai kaitan antara multiple large shareholder dalam mempengaruhi kinerja akuntansi (laba) terhadap insentif kompensasi manajemen. Untuk itu, penelitian ini bertujuan untuk membuktikan secara empiris mengenai peran pemegang saham terbesar kedua (multiple large shareholder) yang dapat mempengaruhi kinerja akuntansi terhadap kompensasi manajemen (direksi).

Penelitian ini mengambil sampel pada semua perusahaan yang terdaftar di Bursa Efek Indonesia, kecuali industri keuangan dan pertambangan dari periode 2017 hingga 2019. Indonesia dipilih menjadi sampel penelitian karena merupakan salah satu negara berkembang yang berada di kawasan Asia Timur, dimana kebanyakan tata kelola perusahaannya masih lemah dan kepemilikannya masih terkonsentrasi (Claessens et al., 2000). Hasilnya menunjukkan bahwa secara konsisten laba berpengaruh secara positif terhadap kompensasi manajemen kunci perusahaan, dimana semakin tinggi laba perusahaan akan berdampak terhadap peningkatan kompensasi manajemen kunci.

Namun, apabila terdapat dua atau lebih pemegang saham terbesar yang memiliki kepemilikan saham $>10 \%$ dan terdapat perwakilan pemegang saham terbesar kedua di jajaran dewan komisaris, maka hal tersebut dapat menurunkan oportunistik manajemen dan mencegah adanya keuntungan pribadi yang ditimbulkan, sehingga kompensasi manajemen akan diawasi oleh pemegang 
saham terbesar kedua yang akan berdampak pada kompensasi manajemen kunci yang tidak terlalu besar dibandingkan perusahaan lainnya.

Temuan dalam penelitian ini memiliki beberapa kontribusi, yaitu pertama memberikan bukti empiris mengenai peran multiple large shareholder yang dapat mempengaruhi kinerja akuntansi terhadap kompensasi manajemen. Kedua, sebagai tambahan literatur di bidang Akuntansi Keuangan dan tata kelola, terutama mengenai pengukuran multiple large shareholder (MLS) yang dilihat dari keberadaan perwakilan pemegang saham terbesar kedua atau ketiga didalam jajaran dewan komisaris yang dapat mengawasi kebijakan manajemen persahaan dan ekspropriasi yang dilakukan pemegang saham terbesar pertama yang belum banyak digunakan dalam penelitian terdahulu di bidang MLS.

Sistematika penulisan dalam penelitian ini terdiri dari lima bagian, yaitu bagian I mengenai pendahuluan, bagian II merupakan studi literatur dan pengembangan hipotesis, bagian III metode penelitian, bagian IV memaparkan hasil penelitian, sedangkan yang terakhir, bagian ke-V merupakan kesimpulan dari penelitian ini.

\section{Teori Terkait Kompensasi Manajemen dan Kinerja Akuntansi}

Umumnya, program insentif kompensasi pada sebuah perusahaan didasarkan pada kinerja akuntansi (laba) dan kinerja pasar (harga saham). Kompensasi tersebut terdiri dari kompensasi kas, bonus, saham, opsi, atau komponen lainnya yang dibayarkan kepada manajemen kunci berdasarkan kinerja perusahaan (Scott, 2012). Peran laba dalam memotivasi kinerja manajer sangat penting sebagaimana peran laba sebagai salah satu informasi bagi para investor. Hal ini dikarenakan dapat memotivasi tanggung jawab dan kinerja manajemen perusahaan, serta meningkatkan produktivitas tenaga kerja (Scott, 2012).

Teori mengenai kompensasi manajemen kunci, kebanyakan dikaitkan dengan teori keagenan dan teori akuntansi positif. Dalam teori keagenan, untuk memitigasi adanya internal dan eksternal konflik keagenan yang terjadi di suatu perusahaan, maka dibutuhkan suatu kontrak perjanjian, seperti misalnya kontrak kompensasi manajemen dan kontrak utang (Fields et al., 2001; Healy, 1985).

Berdasarkan teori akuntansi positif, bagi manajemen sebuah perusahaan yang memiliki program bonus berdasarkan laba, tentunya manajemen akan memilih suatu kebijakan akuntansi tertentu yang dapat meningkatkan laba masa kini maupun laba masa mendatang perusahaan. Hal ini terkait dengan insentif kompensasi yang akan diterimanya yang didasarkan pada laba perusahaan (Watts dan Zimmerman, 1978; Scott, 2012).

Sehingga tujuan diberikannya kontrak kompensasi bagi manajemen kunci yaitu untuk mendorong memilih metode akuntansi yang tepat bagi keuangan perusahaan, mengindari adanya biaya keagenan, pelanggaran perjanjian utang, serta tidak berperilaku oportunis (Watts \& Zimmerman, 1978; Fields et al., 2001; Conyon, 2006, Zulma, G.W.M., 2016).

Dalam mengevaluasi kinerja, permasalahan yang timbul selanjutnya adalah relativitas proporsi terkait evaluasi kinerja berdasarkan laba dan harga saham. Karena, apabila semakin tinggi noise dalam laba perusahaan dan manajer semakin sensitif terhadap besarnya laba, maka semakin besar bagi perusahaan untuk membutuhkan evaluasi kinerja berdasarkan indikator harga saham atau indikator lainnya (Banker dan Datar, 1989).

Peran akuntan dalam meningkatkan sensitivitas besaran laba yang dapat mempengaruhi penilaian kinerja manajemen sangatlah besar, misalnya saja dengan konservatisme pelaporan keuangan, penggunaan historical cost, serta tingkat pengungkapan (disclosure) yang dapat mengevaluasi persistensi dan manajemen laba yang dilakukan manajemen perusahaan (Scott, 2012).

Multiple Large Shareholders dan Masalah Keagenan

Dalam teori keagenan (agency theory) dikatakan bahwa terdapat konflik kepentingan antara agen (manajemen perusahaan) dengan principle (pemilik perusahaan) apabila struktur kepemilikan menjadi tersebar seperti di negara yang pasar modalnya sudah baik seperti di US. Namun dalam konteks di Indonesia, terdapat konflik kepentingan antara pemegang saham pengendali (agen) dan pemegang saham minoritas (principle) apabila struktur kepemilikan terkonsentrasi (Jensen \& Meckling, 1976; Fama \& Jensen, 1983).

OECD telah mencermati pentingnya penerapan tata kelola yang baik di suatu perusahaan. Beberapa prinsip OECD yang terkait dengan tata kelola di suatu perusahaan menyebutkan bahwa harus terdapat persamaan hak antara pemegang saham minoritas dengan pemegang saham pengendali, dan juga dewan komisaris harus dapat mengawasi strategi bisnis yang dilakukan oleh manajemen.

Adanya konflik kepentingan yang terjadi di kalangan pemegang saham membuat para pemegang saham minoritas bergantung pada fungsi pengawasan yang dapat melindungi mereka dari ekspropriasi pemegang saham pengendali (Boubaker \& Sami, 2011). Kehadiran dari investor asing di suatu perusahaan dianggap belum mencukupi untuk mengawasi ekspropriasi dari pemegang saham pengendali, namun di sisi lain kehadiran dari multiple large shareholders dianggap sebagai fungsi pengawasan yang efektif dalam melindungi pemegang saham minoritas.

Multiple large shareholders terjadi ketika terdapat dua atau lebih pemegang saham terbesar yang memiliki hak kendali dan arus kas di suatu perusahaan. Pemegang saham terbesar kedua dapat mengawasi ekspropriasi yang dilakukan oleh pemegang saham terbesar pertama, 
sehingga dapat menurunkan asimetri informasi di kalangan para investor (Attig et al., 2008). Selain itu, Amdouni dan Boubaker (2015) mengungkapkan bahwa apabila di suatu perusahaan terdapat dua atau lebih pemegang saham terbesar, maka hal tersebut dapat menurunkan oportunistik manajemen dan mencegah adanya keuntungan pribadi yang ditimbulkan, sehingga kompensasi manajemen akan diawasi oleh pemegang saham terbesar kedua.

\section{Pengembangan Hipotesis}

Berdasarkan beberapa temuan dari penelitian sebelumnya, Theeravanich (2013) menemukan adanya pengaruh yang positif antara kinerja akuntansi terhadap kompensasi manajemen. Sehingga, semakin tinggi kinerja perusahaan, maka dapat meningkatkan kompensasi manajemen. Sejalan dengan hal itu, Conyon (2006) juga mengemukakan bahwa apabila kinerja keuangan perusahaan turun, maka kompensasi direksi juga akan mengalami penurunan, begitu pula sebaliknya.

Oleh karena itu, manajemen akan semakin sensitif terhadap kinerja akuntansi atau laba perusahaan karena akan mempengaruhi besaran kompensasi yang akan didapatkannya. Sehingga, manajemen akan berupaya untuk memilih suatu kebijakan akuntansi tertentu yang dapat meningkatkan laba masa kini maupun laba masa mendatang perusahaan secara persisten (Watts dan Zimmerman, 1978). Padahal, aktivitas tersebut dapat memunculkan kemungkinan bagi manajemen untuk berupaya meningkatkan kinerja akuntansi (laba) perusahaan secara oportunis terkait dengan kompensasi yang akan diterimanya berdasarkan laba perusahaan tersebut.

\section{H1: Kinerja akuntansi berpengaruh positif terhadap kompensasi manajemen kunci (direksi) di Indonesia}

Menurut Amdouni dan Boubaker (2015), apabila di suatu perusahaan terdapat dua atau lebih pemegang saham terbesar, maka hal tersebut dapat menurunkan oportunistik manajemen dan mencegah adanya keuntungan pribadi yang ditimbulkan, sehingga pemberian insentif kompensasi manajemen akan diawasi oleh pemegang saham terbesar kedua. Dengan demikian, terdapat dugaan bahwa peran dari pemegang saham terbesar kedua dapat memperlemah pengaruh positif kinerja akuntansi terhadap kompensasi manajemen kunci di Indonesia.

H2: Pemegang saham terbesar kedua dapat memperlemah pengaruh positif kinerja akuntansi terhadap kompensasi manajemen kunci (direksi) di Indonesia

\section{METODE}

\section{Populasi dan Sampel}

Populasi dalam penelitian ini adalah semua perusahaan yang terdaftar dalam Bursa Efek Indonesia (BEI), kecuali industri keuangan dan pertambangan. Periode penelitian dimulai pada tahun 2017 hingga 2019. Sumber data dalam penelitian ini merupakan data sekunder yang diambil dari Datastream Worldscope Database dan annual report laporan keuangan perusahaan. Pada tabel 1 terlihat bahwa total sampel yang dapat digunakan sebanyak 474 observasi yang terdiri dari 158 perusahaan. Adapun proses seleksi pengambilan sampel dalam penelitian ini menggunakan metode purposive sampling yang dapat dilihat pada tabel 1 .

Tabel 1. Seleksi Sampel

\begin{tabular}{lcc}
\hline & Tahun Perusahaan & Jumlah Perusahaan \\
\hline Jumlah perusahaan yang terdaftar di BEI per Maret 2020 & 1551 & 517 \\
Dikurangi: & & $(540)$ \\
-Industri keuangan, konstruksi, pertambangan & $(168)$ & $(180)$ \\
-Tidak menggunakan tahun fiskal yang berakhir pada 31 desember & $(369)$ & $(56)$ \\
-Data tidak lengkap dari tahun 2017-2019 & $\mathbf{4 7 4}$ & $(123)$ \\
Total Observasi & $\mathbf{1 5 8}$ \\
\hline
\end{tabular}

Sedangkan statistik deskriptif dapat dilihat pada tabel 2. Dapat terlihat bahwa rata-rata variabel kompensasi direksi sebesar $\mathrm{Rp} 1.43$ milyar rupiah pertahun dengan kompensasi tertinggi sebesar Rp 2.04 milyar pertahun dan minimum kompensasi sebesar Rp 1.10 milyar pertahun. Sedangkan rata-rata tingkat profitabilitas tahun lalu pada periode penelitian juga positif sebesar 1.45 dengan standar deviasi mencapai 0.87 dengan nilai minimum sebesar 0.015 .

Selain itu, perusahaan publik di Indonesia juga kebanyakan struktur kepemilikannya masih terkonsentrasi (single shareholder). Hal ini dapat terlihat dari rata-rata variabel MLS20 yang lebih kecil dibandingkan rata-rata variabel MLS10 yang hanya sebesar $21 \%$ dari total sampel. Sehingga rata-rata perusahaan publik di Indonesia masih sedikit yang memiliki pemegang saham terbesar kedua dengan kepemilikan saham lebih dari 20 persen. Hal ini juga tentunya dapat mempengaruhi penempatan perwakilan pemegang saham terbesar kedua didalam jajaran dewan komisarisnya untuk mengawasi kebijakan manajemen perusahaan.

Perusahaan yang menempatkan perwakilan dari pemegang saham terbesar kedua rata-rata hanya $20 \%$ dari total sampel. Ukuran perusahaan dalam penelitian ini rata-rata 21.31dengan nilai maksimum sebesar 26.07 
Gandy Wahyu Maulana Zulma et al, Transaksi Pihak Berelasi: Kompensasi Manajemen Kunci, Kinerja Akuntansi, dan Multiple Large Shareholders

dan minimum 16.11. Selain itu, dapat terlihat pada tabel 2, bahwa hasil uji multikolinieritas menunjukkan tidak terjadi korelasi yang kuat antar variabel pada model penelitian, karena nilainya tidak mencapai lebih dari 0.8 .

Tabel 2. Statististik Deskriptif dan Korelasi

Panel A: Statistik Deskriptif

\begin{tabular}{lcccccc}
\hline & n & Mean & StDev & Median & Max & Min \\
\hline KOMPDIR $_{\text {it }}$ & 474 & 14.30 & 1.47 & 14.25 & 20.46 & 11.08 \\
ROA $_{\text {it-1 }}$ & 474 & 1.45 & 0.87 & 0.97 & 6.05 & 0.015 \\
${\text { MLS } 20_{\text {it }}}_{\text {MLS10 }}$ & 474 & 0.21 & 0.41 & 0 & 1 & 0 \\
Board_MLS $_{\text {it }}$ & 474 & 0.46 & 0.49 & 0 & 1 & 0 \\
Proshm $_{\text {SIZE }}$ & 474 & 0.20 & 0.40 & 0 & 1 & 0 \\
LEV & 474 & 0.30 & 0.34 & 0.16 & 1 & 0 \\
it & 474 & 21.31 & 1.68 & 21.39 & 26.07 & 16.11 \\
\hline
\end{tabular}

Panel B: Matriks Korelasi Antar Variabel

\begin{tabular}{lcccccccc}
\hline & KOMPDIR & ROA & MLS20 & MLS10 & Board_MLS & Proshm & SIZE & LEV \\
\hline KOMPDIR & $\mathbf{1 . 0 0}$ & & & & & & & \\
ROA & 0.05 & $\mathbf{1 . 0 0}$ & & & & & & \\
MLS20 & $-0.13^{* * *}$ & 0.00 & $\mathbf{1 . 0 0}$ & & & & & \\
MLS10 & $-0.11^{* * *}$ & -0.00 & $0.56^{* * *}$ & $\mathbf{1 . 0 0}$ & & & & \\
Board_MLS & 0.02 & $0.09^{* *}$ & $0.26^{* * *}$ & $0.31^{* * *}$ & $\mathbf{1 . 0 0}$ & & & \\
Proshm & $-0.13^{* * *}$ & -0.06 & $0.66^{* * *}$ & $0.80^{* * *}$ & $0.27^{* * *}$ & $\mathbf{1 . 0 0}$ & & \\
SIZE & $0.60^{* * *}$ & $-0.16^{* * *}$ & $-0.17^{* * *}$ & -0.03 & 0.04 & -0.06 & $\mathbf{1 . 0 0}$ & \\
LEV & -0.06 & $0.08^{*}$ & $0.16^{* * *}$ & $0.13^{* * *}$ & -0.02 & 0.06 & $-0.16^{* * *}$ & $\mathbf{1 . 0 0}$ \\
\hline
\end{tabular}

Keterangan Variabel:

KOMPDIR $_{\text {it }}=$ total kompensasi direksi dibagi jumlah direksi perusahaan $\mathrm{i}$ pada tahun $\mathrm{t} ; R O A_{\text {it }-1}=$ rasio laba sebelum pajak pada tahun $\mathrm{t}-1$ dibagi total aset perusahaan i pada tahun t-1; Variabel MLS: MLS20 (1 jika terdapat 2 atau lebih pemegang saham yang memiliki kepemilikan sahamnya $>20 \%$, 0 selain itu), MLS10 (1 jika terdapat 2 atau lebih pemegang saham yang memiliki kepemilikan sahamnya $>10 \%$, 0 selain itu), Board_MLS (1 jika terdapat perwakilan pemegang saham terbesar kedua di jajaran dewan komisaris 0 selain itu, Proshm (Rasio kepemilikan saham terbesar kedua dibagi pemegang saham pertama); Variabel Kontrol: $S I Z E_{\text {it }}=$ logaritma total aset perusahaan i pada tahun $\mathrm{t}, L E V_{\text {it }}=$ total utang dibagi total aset perusahaan $\mathrm{i}$ pada tahun $\mathrm{t}$.

\section{Model Penelitian}

Penelitian ini merupakan pengembangan penelitian dari Banker et al. (2009) dengan mempertimbangkan adanya peran multiple large shareholder yang dapat berpengaruh terhadap kompensasi manajemen (Amdouni dan Boubaker, 2015). Penggunaan variabel (ROA)_(it-1)dalam mengukur kinerja akuntansi, dikarenakan untuk mencegah adanya permasalahan endogenitas yang muncul antara kinerja perusahaan dan kompensasi manajemen. Adapun model penelitian untuk menguji hipotesis dalam penelitian ini yaitu:

$$
\text { KOMPDIR }_{i t}=\beta_{0}+\beta_{1} R O A_{i t-1}+\beta_{2} R O A_{i t-1} M L S_{i t}+\beta_{3} C_{N O N T O L_{i t}}+u_{i t}
$$

Keterangan:

KOMPDIR $_{\text {it }} \quad=$ Kompensasi kas direksi dibagi jumlah direksi perusahaan i pada tahun $\mathrm{t}$

$R O A_{i t-1} \quad=$ Rasio laba sebelum pajak dibagi ratarata total aset perusahaan $\mathrm{i}$ pada tahun $\mathrm{t}-1$

$\mathrm{MLS}_{\text {it }} \quad=$

- MLS20 (1 jika terdapat 2 atau lebih pemegang saham yang memiliki kepemilikan sahamnya $>20 \%$, 0 selain itu)
- MLS10 (1 jika terdapat 2 atau lebih pemegang saham yang memiliki kepemilikan sahamnya $>10 \%, 0$ selain itu)

- Board_MLS (1 jika terdapat perwakilan pemegang saham terbesar kedua di jajaran dewan komisaris 0 selain itu)

- Proshm (Rasio kepemilikan saham terbesar kedua dibagi pemegang saham pertama)

CONTROL $_{i t}=$

- Size (logaritma total aset perusahaan i pada tahun $\mathrm{t}$ ) 
- Lev (Rasio utang dibagi total aset perusahaan i pada tahun t)

\section{Operasionalisasi Variabel}

Peneliti menggunakan beberapa proksi untuk menilai fungsi pengawasan dalam penegakan tata kelola disuatu perusahaan, menggunakan ukuran yang telah digunakan dalam penelitian Claessens et al. (2000), Attig et al. (2008), serta Boubaker dan Sami (2011). Terdapat empat proksi yang digunakan dalam penelitian ini, yaitu yaitu MLS20 merupakan variabel dummy, 1 jika perusahaan tersebut terdapat dua atau lebih pemegang saham yang kepemilikan sahamnya lebih dari 20 persen (Claessens et al., 2000). Lalu menggunakan MLS10 yaitu variabel dummy, 1 jika perusahaan tersebut terdapat dua atau lebih pemegang saham yang kepemilikan sahamnya lebih dari 10 persen (Boubaker \& Sami, 2011).

Selain itu, dalam penelitian ini juga menggunakan variabel Pro_shm yaitu Rasio kepemilikan saham terbesar kedua dibagi pemegang saham pertama (Attig et al. 2010; Boubaker dan Sami, 2011). Proksi yang keempat yaitu menggunakan Board_MLS, yaitu variabel dummy, 1 jika perusahaan tersebut menempatkan perwakilan pemegang saham terbesar kedua dalam jajaran dewan komisaris yang dapat mengawasi kebijakan manajemen perusahaan.

\section{HASIL DAN PEMBAHASAN}

Sebelum melakukan pengujian data, peneliti menguji apakah hasil regresi yang dilakukan telah terbebas dari permasalahan autokorelasi dan heteroskedastisitas. Peneliti telah menghilangkan permasalahan terjadinya varians yang tidak konstan dan terjadi otokorelasi dalam errornya, maka peneliti mengontrol standar error secara otomatis dengan cara memilih cross-section weights dan white cross-section dalam Eviews. Nilai Durbin Watson dari model return menunjukkan di kisaran angka 2 yang mengindikasikan bahwa hasil regresi tersebut telah terbebas dari permasalahan autokorelasi. Model analisis data yang digunakan dalam penelitian ini adalah analisis Regresi Linier Berganda dengan data panel (pooled data) yang meliputi data cross section dan time series. Dari hasil uji chow dan uji hausman yang dilakukan, analisis data panel menggunakan Random Effect Model.

Tabel 3 menunjukkan adanya pengaruh fungsi pengawasan pemegang saham terbesar kedua di suatu perusahaan pada kinerja keuangan masa lalu terhadap besaran kompensasi yang didapatkan oleh manajemen kunci. Hasilnya, variabel MLS10 dan BoardMLS dapat memperlemah pengaruh positif kinerja terhadap kompensasi manajemen. Nilai koefisien variabel $R O A_{i t-1} * M L S 10_{i t}$ pada persamaan 2 sebesar -0.13 dengan signifikansi level 10\%, Hal ini menunjukkan bahwa apabila terdapat pemegang saham terbesar kedua yang memiliki saham diatas $10 \%$ pada perusahaan tersebut, maka dapat memperlemah pengaruh positif kinerja terhadap kompensasi.

Nilai koefisien variabel $R O A_{i t-1} *$ BoardMLS pada persamaan 3 sebesar -0.16 dengan signifikansi level 5\%. Hal ini mengindikasikan bahwa apabila terdapat perwakilan pemegang saham terbesar kedua pada jajaran dewan komisaris, maka dapat memperlemah pengaruh positif kinerja terhadap kompensasi manajemen. Keberadaan perwakilan dari pemegang saham terbesar kedua pada jajaran dewan komisaris dapat menurunkan oportunistik manajemen dan mencegah adanya keuntungan pribadi yang ditimbulkan, sehingga kompensasi manajemen akan diawasi oleh pemegang saham terbesar kedua yang akan berdampak pada kompensasi manajemen kunci yang tidak terlalu besar dibandingkan perusahaan lainnya. Hal ini sesuai dengan pernyataan Amdouni dan Boubaker (2015) yang menemukan bahwa apabila di suatu perusahaan terdapat dua atau lebih pemegang saham terbesar, maka hal tersebut dapat menurunkan oportunistik manajemen dan mencegah adanya keuntungan pribadi yang ditimbulkan, sehingga kompensasi manajemen akan diawasi oleh pemegang saham terbesar kedua.

Selain itu, Attig et al. (2008) mengemukakan apabila terdapat dua atau lebih pemegang saham terbesar di suatu perusahaan, maka pemegang saham kedua dapat melakukan pengawasan terhadap pemegang saham terbesar yang pertama. Sehingga keberadaan pemegang saham terbesar kedua penting adanya, karena dapat mengawasi adanya kemungkinan ekspropriasi terhadap pemegang saham minoritas di perusahaan keluarga.

Tabel 3. Hasil Uji Regresi

\begin{tabular}{|c|c|c|c|c|c|}
\hline \multirow{2}{*}{ Variabel } & \multirow{2}{*}{ Sign } & \multicolumn{4}{|c|}{ Dependen Variabel: KOMPDIR } \\
\hline & & $\operatorname{MLS20}(1)$ & $\operatorname{MLS10}(2)$ & Board_MLS (3) & Proshm (4) \\
\hline Intercept & & $\begin{array}{c}2.72 * * * \\
(2.66)\end{array}$ & $\begin{array}{c}2.70 * * * \\
(2.66)\end{array}$ & $\begin{array}{c}2.62 * * * \\
(2.58)\end{array}$ & $\begin{array}{c}2.72 * * * \\
(2.68)\end{array}$ \\
\hline$R O A_{\text {it }-1}$ & + & $\begin{array}{l}\mathbf{0 . 3 0} * * * \\
(5.15)\end{array}$ & $\begin{array}{c}\mathbf{0 . 3 6} * * * \\
(5.23)\end{array}$ & $\begin{array}{c}\mathbf{0 . 3 5} * * * \\
(5.40)\end{array}$ & $\begin{array}{c}\mathbf{0 . 3 4} * * * * \\
(5.01)\end{array}$ \\
\hline$R O A_{\text {it }-1} * M L S 20_{\text {it }}$ & - & $\begin{array}{l}-0.05 \\
(-0.63)\end{array}$ & & & \\
\hline$R O A_{\text {it }-1} * M L S 10_{\text {it }}$ & - & & $\begin{array}{l}-0.13 * \\
(-1.76)\end{array}$ & & \\
\hline
\end{tabular}


Gandy Wahyu Maulana Zulma et al, Transaksi Pihak Berelasi: Kompensasi Manajemen Kunci, Kinerja Akuntansi, dan Multiple Large Shareholders

\begin{tabular}{|c|c|c|c|c|c|}
\hline$R O A_{\text {it }-1} *$ BoardMLS $S_{\text {it }}$ & - & & & $\begin{array}{c}-0.16 * * \\
(-1.79)\end{array}$ & \\
\hline$R O A_{\text {it }-1} *$ Proshm $_{\text {it }}$ & - & & & & $\begin{array}{c}-0.15 \\
(-1.27)\end{array}$ \\
\hline SIZE & + & $\begin{array}{c}0.52 * * * \\
(11.34)\end{array}$ & $\begin{array}{c}0.52 * * * \\
(11.42)\end{array}$ & $\begin{array}{c}0.52 * * * \\
(11.47)\end{array}$ & $\begin{array}{c}0.52 * * * \\
(11.39)\end{array}$ \\
\hline$L E V$ & & $\begin{array}{l}0.10 * \\
(1.70)\end{array}$ & $\begin{array}{c}0.11 * * \\
(1.84)\end{array}$ & $\begin{array}{c}0.09 \\
(1.49)\end{array}$ & $\begin{array}{l}0.10^{*} \\
(1.69)\end{array}$ \\
\hline Jumlah observasi & & 474 & 474 & 474 & 474 \\
\hline F-Statistic & & 33.15 & 34.16 & 33.88 & 33.70 \\
\hline $\mathrm{R}^{2}$ & & 0.22 & 0.22 & 0.22 & 0.22 \\
\hline Adjusted $\mathrm{R}^{2}$ & & 0.21 & 0.21 & 0.21 & 0.21 \\
\hline
\end{tabular}

Keterangan Variabel:

KOMPDIR $_{\text {it }}=$ total kompensasi direksi dibagi jumlah direksi perusahaan i pada tahun $\mathrm{t} ; R O A_{\text {it }-1}=$ rasio laba sebelum pajak pada tahun t-1 dibagi total aset perusahaan i pada tahun t-1; Variabel MLS: MLS2O (1 jika terdapat 2 atau lebih pemegang saham yang memiliki kepemilikan sahamnya $>20 \%$, 0 selain itu), MLS1O (1 jika terdapat 2 atau lebih pemegang saham yang memiliki kepemilikan sahamnya $>10 \%$, 0 selain itu), Board_MLS (1 jika terdapat perwakilan pemegang saham terbesar kedua di jajaran dewan komisaris 0 selain itu, Proshm (Rasio kepemilikan saham terbesar kedua dibagi pemegang saham pertama); Variabel Kontrol: $S I Z E_{\text {it }}=\operatorname{logaritma}$ total aset perusahaan i pada tahun $\mathrm{t}, L E V_{\text {it }}=$ total utang dibagi total aset perusahaan $\mathrm{i}$ pada tahun t.Tanda $* * *$, **,dan $*$ mengindikasikan signifikansi level 0.01, 0.05, dan 0.10.

Pada tabel 3 juga menunjukkan bahwa variabel $R O A_{\text {it-1 }}$ secara konsisten berpengaruh positif terhadap kompensasi manajemen (KOMPDIR dan
LNKOMPDIR). Hal ini menunjukkan bahwa kinerja akuntansi (laba) berpengaruh secara positif terhadap kompensasi manajemen kunci perusahaan, dimana semakin tinggi laba perusahan akan berdampak terhadap peningkatan kompensasi manajemen kunci. Hasil ini konsisten dengan penelitian Theeravanich (2013) yang menemukan adanya pengaruh positif antara kinerja terhadap kompensasi.

Namun demikian, variabel MLS20 dan Proshm tidak memiliki pengaruh antara kinerja akuntansi terhadap besaran kompensasi manajemen. Hal ini menunjukkan bahwa apabila terdapat pemegang saham terbesar kedua yang memiliki saham diatas $20 \%$ justru tidak dapat memperlemah pengaruh positif kinerja terhadap kompensasi manajemen. Selain itu, rasio hak kontrol antara pemegang saham pertama dengan pemegang saham kedua, tidak dapat memperlemah pengaruh positif kinerja terhadap besaran kompensasi manajemen.

Tabel 4. Analisis Sensitivitas

\begin{tabular}{|c|c|c|c|c|c|}
\hline \multirow{2}{*}{ Variabel } & \multirow{2}{*}{ Sign } & \multicolumn{4}{|c|}{ Dependen Variabel: LNKOMPDIR } \\
\hline & & MLS20 (1) & MLS10 (2) & Board_MLS (3) & Proshm (4) \\
\hline Intercept & & $\begin{array}{c}2.64 * * * \\
(2.70)\end{array}$ & $\begin{array}{c}2.63 * * * \\
(2.71)\end{array}$ & $\begin{array}{c}2.56^{* * * *} \\
(2.62)\end{array}$ & $\begin{array}{c}2.65 * * * \\
(2.73)\end{array}$ \\
\hline$R O A_{\text {it }-1}$ & + & $\begin{array}{l}\mathbf{0 . 3 0} * * * \\
(5.67)\end{array}$ & $\begin{array}{c}0.38 * * * \\
(5.95)\end{array}$ & $\begin{array}{c}0.35^{* * * *} \\
(6.03)\end{array}$ & $\begin{array}{c}0.35^{* * * *} \\
(5.66)\end{array}$ \\
\hline$R O A_{\text {it }-1} * M L S 20_{\text {it }}$ & - & $\begin{array}{l}-0.04 \\
(-0.56)\end{array}$ & & & \\
\hline$R O A_{\text {it }-1} * M L S 10_{\text {it }}$ & - & & $\begin{array}{l}-0.14 * * \\
(-2.18)\end{array}$ & & \\
\hline$R O A_{\text {it }-1} *$ BoordMLS $S_{\text {it }}$ & - & & & $\begin{array}{l}-0.17 * * \\
(-2.05)\end{array}$ & \\
\hline$R O A_{\text {it }-1} *$ Proshm $_{\text {it }}$ & - & & & & $\begin{array}{l}-0.17 \\
(-1.58)\end{array}$ \\
\hline SIZE & + & $\begin{array}{c}0.59 * * * \\
(13.51)\end{array}$ & $\begin{array}{c}0.59 * * * \\
(13.61)\end{array}$ & $\begin{array}{l}0.60^{* * * *} \\
(13.64)\end{array}$ & $\begin{array}{l}0.59 * * * \\
(13.58)\end{array}$ \\
\hline$L E V$ & & $\begin{array}{c}0.08 \\
(1.50)\end{array}$ & $\begin{array}{l}0.09 * \\
(1.71)\end{array}$ & $\begin{array}{c}0.06 \\
(0.19)\end{array}$ & $\begin{array}{c}0.08 \\
(1.52)\end{array}$ \\
\hline Jumlah observasi & & 474 & 474 & 474 & 474 \\
\hline F-Statistic & & 46.28 & 47.98 & 47.31 & 47.36 \\
\hline $\mathrm{R}^{2}$ & & 0.28 & 0.29 & 0.28 & 0.28 \\
\hline Adjusted $\mathrm{R}^{2}$ & & 0.27 & 0.28 & 0.28 & 0.28 \\
\hline
\end{tabular}


Keterangan Variabel:

KOMPDIR $_{\text {it }}=$ total kompensasi direksi dibagi jumlah direksi perusahaan i pada tahun $\mathrm{t}$; $R O A_{\text {it }-1}=$ rasio laba sebelum pajak pada tahun $\mathrm{t}-1$ dibagi total aset perusahaan i pada tahun t-1; Variabel MLS: MLS20 (1 jika terdapat 2 atau lebih pemegang saham yang memiliki kepemilikan sahamnya $>20 \%$, 0 selain itu), MLSIO (1 jika terdapat 2 atau lebih pemegang saham yang memiliki kepemilikan sahamnya $>10 \%$, 0 selain itu), Board_MLS (1 jika terdapat perwakilan pemegang saham terbesar kedua di jajaran dewan komisaris 0 selain itu, Proshm (Rasio kepemilikan saham terbesar kedua dibagi pemegang saham pertama); Variabel Kontrol: $S I Z E_{\text {it }}=$ logaritma total aset perusahaan i pada tahun $\mathrm{t}, L E V_{\text {it }}=$ total utang dibagi total aset perusahaan $\mathrm{i}$ pada tahun t.Tanda $* * *$, **, dan * mengindikasikan signifikansi level 0.01, 0.05, dan 0.10 .

Pada tabel 4, dilakukan analisis sensitivitas dengan mengganti pengukuran variabel dependen dengan menggunakan ukuran logaritma natural dari total kompensasi direksi. Hasilnya konsisten dengan tabel 3. Variabel MLS10 dan Board_MLS dapat memperlemah pengaruh positif kinerja akuntansi terhadap besaran kompensasi direksi dengan nilai koefisien sebesar -0.14 dan -0.17 dengan signifikansi level 5\%. Sedangkan variabel MLS20 dan Proshm secara konsisten sama dengan hasil pada tabel 3, yaitu tidak terbukti dapat memperlemah pengaruh kinerja terhadap kompensasi manajemen kunci (direksi).

\section{SIMPULAN}

Dalam penelitian ini dibahas mengenai dampak dari fungsi pengawasan multiple large shareholder dalam mempengaruhi kinerja akuntansi terhadap kebijakan besaran kompensasi manajemen kunci pada perusahaan publik di Indonesia. Secara umum, laba berpengaruh secara positif terhadap kompensasi manajemen perusahaan, dimana semakin tinggi laba perusahan akan berdampak terhadap peningkatan kompensasi manajemen kunci.

Namun, apabila terdapat dua atau lebih pemegang saham terbesar yang memiliki kepemilikan saham $>10 \%$ dan terdapat perwakilan pemegang saham terbesar kedua di jajaran dewan komisaris, maka hal tersebut dapat menurunkan oportunistik manajemen dan mencegah adanya keuntungan pribadi yang ditimbulkan, sehingga kompensasi manajemen akan diawasi oleh pemegang saham terbesar kedua yang akan berdampak pada kompensasi manajemen kunci yang tidak terlalu besar dibandingkan perusahaan lainnya.

Temuan dalam penelitian ini dapat menjadi bahan masukan bagi perkembangan penelitian di bidang akuntansi keuangan dan tata kelola. Selain itu temuan ini dapat menjadi bahan masukan bagi OJK (Otoritas Jasa
Keuangan) dalam upaya menegakkan aturan mengenai pemegang saham terbesar kedua di Indonesia. Karena pemegang saham terbesar kedua memiliki peranan yang penting dalam mengawasi adanya peluang manajemen yang oportunis apabila perusahaan tersebut menggunakan program bonus pada kompensasinya.

Tentunya penelitian ini masih terdapat keterbatasan, seperti kinerja perusahaan hanya dilihat dari kinerja akuntansi (laba) perusahaan, sampel pengamatan hanya di Indonesia, pengukuran kompensasi hanya berbasis kas dan tidak melihat kompensasi berbasis saham. Selain itu, variabel MLS yang digunakan hanya terbatas pada empat variabel saja. Sehingga penelitian kedepannya diharapkan dapat memperluas dan mengisi kekurangan tersebut dengan menambahkan isu-isu lain terkait multiple large shareholder, relativitas proporsi antara kinerja akuntansi dan kinerja pasar, dan melihat dampaknya terhadap skema pemberian insentif kompensasi manajemen.

\section{DAFTAR PUSTAKA}

Amdouni, S., \& Boubaker S. (2015). Multiple Large Shareholders and Owner-Manager Compensation: Evidence from French Listed Firms. The Journal of Applied Business Research, 31, 3.

Attig, N., Guedhami, O., \& Mishra, D. (2008). Multiple Large Shareholders, Control Contests, and Implied Cost of Equity. Journal of Corporate Finance, 14, 721-737.

Banker, R.D., Lee, S.Y., Potter, G. (1996). A Field Study of the Impact of a PerformanceBasedIncentive Plan. Journal of Accounting and Economics, 21, 195-226.

Banker, R.D., \& Datar, S. (1989). Sensitivity, Precision, and Linear Aggregation of Signals for Performance Evaluation. Journal of Accounting Research, 21-39.

Boubaker, S., \& Sami, H. (2011). Multiple Large Shareholders and Earnings Informativeness. Review of Accounting and Finance, Emerald, 10, 3, 246-266.

Chen, H. W. (2013). Family Ties, Board Compensation, and Firm Performance. Journal of Multinational Financial Management, 23, 255-271.

Cheng, M., Lin B., \& Wei, M. (2015). Executive Compensation in Family Firms: The Effect of Multiple Family Members. Journal of Corporate Finance, 32, 238-257

Cheng, Q., dan Farber, D.B. (2008). Earnings Restatement, Changes in CEO Compensation, and Firm Performance. The Accounting Review, 83, 5, 1217-1250.

Claessens, S., Djankov, S., \& Lang, L.H.P. (2000). The Separation of Ownership and Control in East Asian Corporations. Journal of Financial Economics, 58, 81-112. 
Conyon, M.J. (2006). Executive Compensation and Incentives. Academy of Management Perspectives, 20, 1, 25-44.

Fama, E.F., Jensen, M.C. (1983). Separation of Ownership and Control. Journal of Law and Economics, 26, 2, 301-325.

Fields, T.D., Lys T.Z., Linda V. (2001). Empirical Research on Accounting Choice. Journal of Accounting and Economics, 255-307.

Fisher, J.G., Laureen, L.A., Peffer, dan Sprinkle. (2005). An Experimental Investigation of Employer Discretion in Employee Performance Evaluation and Compensation. The Accounting Review, 80, 2, 563-583.

Healy, P. (1985). The Impact of Bonus Schemes on the Selection of Accounting Principles. Journal of Acconting and Economics, 7, 85-107.

Jensen, M.C., \& Meckling, W.H. (1976). Theory of the Firm: Managerial Behavior, Agency Costs, and Ownership Structure. Journal of Financial Economics, 3, 4, 305-360.

Parthasarathy, A., Menon, K., \& Bhattacherjee, D. (2006). Executive Compensation, Firm Performance and Governance: An Empirical Analysis. Economic and Political Weekly, 41, 39, 4139-4147.

Scott, W.R. (2012). Financial Accounting Theory 6th $E d$. Pearson Prentice Hall: Canada

Theeravanich, A. (2013). Director Compensation in Emerging Markets: A Case Study of Thailand. Journal of Economics and Business,70, 71-91.

Watts, R.L. \& Zimmerman, J.L. (1978). Towards a Positive Accounting Theory of the determination of Accounting Standards. Accounting Review, 54, 273-305.

Zulma, G.W.M. (2016). Family Ownership, Management Compensation, And Tax Avoidance: Evidence From Indonesia. The Indonesian Journal of Accounting Research, 19, 97-110. 